\title{
NERINT STRATEGIC ANALYSIS
}

In 202I, the covid-I9 pandemic continues to dominate the international scene, but that does not mean that the political cleavages and tensions lost their space. In this edition, relevant themes are analyzed, such as the reasons for the recent clashes that affect national stability in Angola, a promising African state. Next, two articles address the issue of the Russian opponent Navalny and the situation in eastern Ukraine, showing little-known dimensions about these two themes. As for the set of problems that concern the containment of China by the United States and the United Kingdom, the subject that was selected was that of the demonstrations in Hong Kong in 2019 and 2020 , which brings an original and thought-provoking analysis.

Vaccine diplomacy also emerged as a new topic, with political-strategic and economic dimensions that go beyond the global health crisis, and was objectively assessed here. Another event that surprised many analysts was the military coup in Myanmar, which has both an internal and an external dimension and is addressed here from a critical perspective. Then, an overview of the first Ioo days of the Biden administration in the diplomatic and security fields is offered, confirming the predictions expressed in the previous issue that the foreign policy changes would rely on form, and not so much on content. Finally, the return of leftist candidates to power in Latin America is analyzed, exploring the fluidity and uncertainty of the regional political framework.

The analysis of the conjuncture, more than just explaining specific events, can contribute to the understanding of ongoing processes and the structure that is taking shape. In this sense, the covid-I9 pandemic, regardless of its origin (will we ever know for sure?), has been addressed, as it appears, in an ineffectual way even by prosperous and organized countries. Thus, a strategic reflection shows that the health crisis may be serving as a cover for another one, which was already manifesting itself in previous years: the economic slowdown. All social difficulties would now be presented as a result of the pandemic, as well as the political morass within the states of the system, and conflicts between them would be justified or camouflaged. So, here is a question for reflection: is the ongoing situation being used, to a large extent, as an opportune instrument for managing the economic crisis and the technological and geopolitical dispute currently underway?

Paulo Fagundes Visentini

Coordinator 


\section{Angola Coping with Multiple Crises}

Analúcia Danilevicz Pereira ${ }^{\mathrm{I}}$

The multiple international crises have had an impact on African countries at the political and economic level, but not only. While seeking to combat the spread of covid-I9 in their territories, many African countries have to deal with serious security crises. In the Sahel, attacks by extremists continued to occur throughout 2020 in Burkina Faso, Mali, Chad and Niger, targeting civilian populations. In northern Nigeria, Boko Haram's actions intensified, which included, in October, the kidnapping of hundreds of students at a school in the city of Katsina. In the east of the continent, a separatist uprising in Ethiopia caused several deaths and thousands of refugees, who took shelter in Sudan. In Mozambique, rebels occupied important parts of Cabo Delgado province (a region rich in mineral resources), causing a large displacement of people towards Nampula, and in Angola, recently, there were armed conflicts in the province of Lunda Norte.

The consolidation of African states, as a rule, has been marked by new power struggles that cannot be separated from the international economic insertion of these countries, especially those that have been demonstrating the capacity for growth and diversification of their economies. It is interesting to note that a new wave of internal conflicts occurs precisely in the countries that stand out, either in their regional space, or in international interactions of a new type. In this sense, such conflicts cannot be separated from the challenges faced (at national and international levels) by states that have demonstrated, in the last decades, greater capacities in terms of resources of power.

In the case of Angola, the Movement for the Liberation of Angola (MPLA), the party that has governed the country since its independence, has been the focus of protest movements (including armed ones) and opposition offensives. Although destabilizing events, such as the performance of separatist forces in Cabinda, in 2006, were circumvented, once again the Angolan government had to respond to demonstrations that confront the integrity and sovereignty of the state.

The Angolan economy is essentially focused on oil exploration, which

I Professor of International Relations/UFRGS. Coordinator of the Brazilian Center for African Studies (CEBRAFRICA/UFRGS) and researcher at the Brazilian Center for Strategy and International Relations (NERINT/UFRGS). The author thanks Isabella Cruzichi and Cecília Maieron Pereira, assistant researchers at CEBRAFRICA, for collecting the data. 
makes up more than $95 \%$ of exports and half of the state's budget revenue. The country is the second largest oil producer in Africa, having been the first on the continent between 2016 and 20I7. However, since 2016, largely due to the fall in oil prices, national production has been gradually decreasing. In parallel, important investments were made in the natural gas sector. After obtaining the highest historical value of GDP in 2014 (US \$ I45.7 billion), the national economy entered a recession, although there was a small recovery in 2017 (US \$ I22.I billion). However, Angola remains one of the five largest economies in sub-Saharan Africa, and the second largest in southern Africa.

The Angolan government, in response to the difficulties, started to defend "macroeconomic stability", private investment and the diversification of the economy, thus initiating a series of reforms such as the introduction of value added tax, the law of fiscal responsibility, the liberalization of the exchange rate regime and a privatization and private investment law. The health crisis and the devaluation price of a barrel of oil in 2020 , aggravated already established processes. However, the price recovery in the last months of 2020 has caused oil revenues to exceed expectations. On the other hand, Angola stands out for being one of the countries most benefited by the Suspension of Debt Service (DSSI), organized by the G20, which provided for the postponement of the payment of debt to official creditors until December 2020 , with the possibility of extension until the end of 202I, which allowed the country to save about $4.3 \%$ of GDP.

The conjuncture of multiple international crises that impacted the country's economic and political reality created a fertile ground for localized disputes, but not isolated from the broader opposition's initiatives to destabilize the MPLA government. On January 30, 202I, in Cafunfo, a village in the province of Lunda Norte, armed demonstrators attacked a national police station resulting in dozens of deaths. The demonstrations were led by the Lunda Tchokwe Portuguese Protectorate Movement (MPPLT), founded in 2006, which claims independence from Angola based on the colonial period treaties signed between Portuguese authorities and regional leaders that would guarantee sovereignty similar to the islands of Madeira and Azores. The leader of the group and coordinator of the attack, José Zecamutchima, was detained by the Luanda Criminal Investigation Service. These recent demonstrations do not claim only independence, but, of course, control over the resources that exist there. Lunda Norte is a region rich in diamonds and the Angolan state diamond company Endiama and Gemcorp, an investment fund management group, based in London, announced an agreement for the development of a diamond project in the province.

The National Union for the Total Independence of Angola (UNITA), 
Broad Convergence for the Salvation of Angola (CASA), Catholic leaders and the European Union harshly criticized the MPLA government in relation to the confrontation between national forces and the MPPLT, on the grounds of disproportionate use of force in state action. However, despite the revolt against the national government, in the presidential elections (20I7), the MPLA obtained the majority of votes, $66.66 \%$, against $22.93 \%$, obtained by UNITA. In this sense, it is worth mentioning some considerations about the political scene in Angola.

In the last elections held in the country in 20I7, the MPLA won again with 6I.I\% of the votes, although this percentage represented a drop in relation to the 2012 elections, when the Party obtained $72 \%$ of the votes. José Eduardo dos Santos was then replaced by João Lourenço, former Minister of Defense, as president of the country. In addition, UNITA was the next most voted party, accounting for $26.7 \%$ of the votes. Throughout 2020 , UNITA organized several demonstrations in Luanda, urging the population to question the government in relation to the high level of unemployment and the cost of living, as well as promoting accusations of state corruption, against the backdrop of the global health crisis.

In March 202I, the Lourenço government announced to the Council of Ministers a proposal for a constitutional review, which would cover 40 articles of the Charter, defending the need to preserve stability in Angola. The initiative around the constitutional revision proposal, from a political point of view, allowed the MPLA to dominate the agenda and put UNITA in an uncomfortable situation, without effective counter-proposal or wellelaborated criticisms about its own project or perspective.

Among the revision proposals, we highlight the removal of gradualism for the installation of municipalities; the determination of a fixed period for general elections; the right to vote for Angolans living abroad and the administrative independence of the Central Bank in relation to the Executive, whose direction continues to be indicated by the President of the Republic, but now with Parliament's endorsement; the integration of the Chief Justice Judge of the Supreme Court to the Council of the Republic, which will be expanded from Io to I5 members; and the creation of a Government of Current Management, which would act at the end of the President's mandate, which would be prevented from taking decisions that may compromise his successor.

Under the first aspect, the municipalities are a proposal to decentralize the country's power and administration. The proposed reforms aim to provide municipalities with their own budget, disconnecting them from the General State Budget. However, the holding of local elections for municipalities, 
which were scheduled to be held in 2020 , for the first time in the country's history, were again postponed due to the covid-I9 pandemic. The crisis scenario also delayed the approval of the Municipal Legislative Package and the postponement of the elections generated numerous criticisms among the opposition. However, such proposals, although representing political decentralization initiatives, place the MPLA in the position of the main interlocutor with different political, economic and social sectors.

Regarding the second aspect, the presidential elections in Angola take place indirectly, as determined by the country's last Constitution, drawn up in 20I0. The president-elect is the candidate that occupies the first position on the list of the most voted party. Contrary to this model, a front of opposition to the government formed by UNITA, the Democratic Bloc (DB) and the Angolan Renaissance Party - Together for Angola - Serving Angola (PRA-JA Servir Angola), released a Joint Political Declaration on the Review Punctual Constitutional in which they indicate the need for direct elections for the country's Executive. Evidently, the opposition's initiative is related to the inability of the other parties to face the MPLA in the short term. In this sense, an important effect of these events in Angolan politics that must be analyzed and monitored concerns the future elections in the country. These are scheduled to be held in the year 2022, when Lourenço is serving his fiveyear presidential term.

It is clear that João Lourenço, at the political level, created conditions, by proposing a constitutional revision, for the emptying and discrediting of opposition criticisms, which intensified in the context of the health crisis and the resulting economic crisis. Some analysts even refer to this action as "a masterstroke" by Lourenço. On the other hand, at the economic level, Lourenço seeks to remake the country's economic profile, promoting a positive image for attracting assets from abroad and, internally, articulating changes, under control, such as the Central Bank's autonomy. Formal mechanisms for political decentralization and economic liberalization are being put on the table. However, the central government's coordination capacity has been strengthened and expanded. This apparent ambiguity reveals the strength of the state project in Angola. 


\section{The Navalny Case}

Rodrigo Ianhez ${ }^{2}$

Less than three months after taking over the presidency of the United States of America, Joe Biden caused a diplomatic crisis by characterizing the President of the Russian Federation, Vladimir Putin, as a murderer and even claiming that his Russian counterpart had no "soul". Metaphysical issues aside, the provocation was clearly motivated by the whole situation that has unfolded since last year involving the Russian opponent Alexei Navalny, notorious for enjoying greater support abroad than within Russia itself.

In August 2020, the anti-corruption blogger and opposition activist Alexei Navalny reportedly suffered a poisoning attempt, after which he was taken to be treated in Germany. The German government promptly claimed to have evidence, which it did not provide, that Navalny was poisoned with the neurotoxic chemical agent Novichok. Such a scenario allows an association of this case with other possible political attacks attributed to the Russian security services, such as the Skripal case, in which a dissident would have been poisoned with the same substance in the UK in 20I8. Quickly, the already worn out relations between the Russian Federation, the US and the European bloc once again reached a historic low, with new sanctions and barbs exchanges.

However, it is necessary to demystify the figure of Navalny which has been portrayed by the Western media as a representative of a powerful leadership with real chances of threatening the Putin government. The operating platform on which Navalny has achieved its greatest reach is YouTube, where his video about a palace under construction that supposedly had belonged to Putin surpassed the fantastic mark of Ioo million views worldwide. However, the growth in Navalny's popularity within Russia is confined to younger age groups, with greater access to the internet and foreign communication channels. Of the total population in the country, 54\% do not like Navalny and $55 \%$ do not believe he has been poisoned ${ }^{3}$. In a poll conducted in October 2020, in the heat of the controversy over Navalny's poisoning, he reached only fourth place among the most trusted figures among Russians, behind President Putin, Foreign Minister Serguei Lavrov and of

\footnotetext{
2 Historian from Moscow State University.

3 Levada.ru. 2020. “Aleksej Navalnyj Otnoshenie I Otravlenie”. Levada, October 02, 2020. https://www.levada.ru/2020/10/02/aleksej-navalnyj-otnoshenie-i-otravlenie/. Access on Jan. I6, $202 \mathrm{I}$.
} 
ultra-nationalist politician Vladímir Zhirinovsk 4 . Among the controversies that do not contribute to Navalny's popularity is an episode in which he was condemned for defaming a World War II veteran, in a country where victory over Nazi Germany is seen as an almost sacred act. He characterized the 95-year-old veteran who had participated in the advertising campaign in support of constitutional amendments that, among other measures, authorized Putin to run for new presidential terms, such as a "traitor", a "shame for the country" and a "corrupt puppet".

Even among the opposition, Navalny is far from being a consensus. Its longstanding links with far-right movements, namely with the organizers of the Russian March, an annual demonstration that brings together nationalists in which Navalny has already participated, shame the central-left wings of anti-Putin movements. Likewise, the support that Navalny offered to the chauvinist movement "Enough Feeding the Caucasus" and the racist rhetoric promoted by the oppositionist in videos on his channel, most notably in a video in which he compares Muslims to cockroaches and simulates shooting a woman dressed in a burqa, are a cause of disagreement between different opposition groups ${ }^{6}$. At the international level, these contradictions have not gone unnoticed either, motivating Amnesty International to withdraw from Navalny the status of "prisoner of conscience" due to the hate speech propagated by the activist?

Such issues, coupled with the opponent's support for Russian intervention in Abkhazia and South Ossetia in 2008, and the Russians' permanence in these separatists regionsi ${ }^{8}$ and their dubious positions in relation to Crimea and Ukraine9, also raise doubts among the liberal sectors

4 Kommersant. ru. 2020. “"Ромир» опубликовал рейтинг доверия россиян”. Kommersant, October 24, 2020. https://www.kommersant.ru/doc/4547667. Access on Jan. I6, 202I.

5 DW News. 202I. “Alexei Navalny fined for ‘defaming’ Russian veteran”. DW News, February 20, 202I. https://www.dw.com/en/alexei-navalny-fined-for-defaming-russian-veteran/a-56635IOI. Access on Feb. 20, 202I.

6 Washington Post. 202I. "We need to have a talk about Alexei Navalny". Washington Post, March 03, 202I. https://www.washingtonpost.com/opinions/202I/O3/OI/we-need-have-talkabout-alexei-navalny/. Access on Mar. 03, 2021.

7 O Globo. 202I. "Anistia Internacional deixa de considerar Navalny um "prisioneiro de consciência”". O Globo, February 24, 202I. https://oglobo.globo.com/mundo/anistiainternacional-deixa-de-considerar-navalny-um-prisioneiro-de-consciencia-24896404. Access on Feb. 24, 202I.

8 Ogdem, Tim. 2020. "Why Navalny may not be a friend of the West". Spectator, August 3I, 2020. https://www.spectator.co.uk/article/why-navalny-may-not-be-a-friend-of-the-west. Access on Apr. OI, 202I.

9 Faraponov, Vladyslav. 202I. "What does Aleksey Navalny Really Think About Ukraine 
of the opposition. In any case, despite not having consensual support, it is undeniable that Navalny managed to broaden his bases since the alleged poisoning episode.

However, the expansion of its support base occurs from a much smaller universe than the Western media coverage seems to indicate. In 2013 , only $6 \%$ of Russians supported Navalny's actions, this number jumped to $20 \%$ in 2020 . At the same time, the percentage of citizens who do not approve Navalny jumped from $35 \%$ to $50 \%$, in the same period. This occurs as the figure of Navalny becomes better known. In 2013, when he was welcomed in the West as the leader of the Russian opposition, Navalny was unknown to $59 \%$ of Russians, today I $8 \%$ say they have not heard of him ${ }^{\mathrm{IO}}$.

This considerable increase in Navalny's relevance within Russian politics is undoubtedly due to all the publicity surrounding the alleged poisoning case and the ensuing protests. The numbers, however, do not yet point to a real threat to the dominion that Putin exercises in Russia's political life. The Russian President, since his return to power after the Medvedev hiatus, has experienced at least three major waves of protest, in 20II-2013, in 20I7-20I8 and now, in January 202I. The latter caused the largest volume of arrests of demonstrators in a relatively short period of time, however, it has been losing momentum. The last demonstration on February I4, held in a new format, with lanterns on city streets, had a considerably smaller impact.

The most massive protests in January of this year, on the other hand, also provoke quite adverse reactions among the Russian population. The unsuspected Levada research institute found that $80 \%$ of Russians were aware of the demonstrations in favor of Navalny. Of these, only $22 \%$ have a positive opinion in relation to the protesters, with $39 \%$ having a negative opinion, and $37 \%$ taking a neutral position. These numbers are in stark contrast to the support of $47 \%$ of respondents in relation to protests in the Khabarovsk region, which began last year in favor of former governor Serguei Furgal of the Liberal Democratic Party of Russia of Vladimir Zhirinovski. Those protests gathered a considerably broader base than those in support of Navalny ${ }^{\text {II }}$.

In short, it is evident that with the support of the Western media and with the mastery of the language of social networks and YouTube, Alexei

Crimea and Donba". Ukraine World, January 2I, 202I. https://ukraineworld.org/articles/ opinions/what-does-aleksey-navalny-really-think-about-ukraine-crimea-and-donbas. Access on Jan. 2I, 2O2I.

Io Levada.ru. 2020. “АЛЕКСЕЙ НАВАЛЬНЫЙ: ОТНОШЕНИЕ И ОТРАВЛЕНИЕ”. Levada, October O2, 2020. https://www.levada.ru/2020/10/02/aleksej-navalnyj-otnoshenie-iotravlenie/. Access on Apr. I6, 2021.

II Levada. ru. 202I. "Yanvarskie Protesty". Levada. February Iо, 202I. https://www.levada. $\mathrm{ru} / 202 \mathrm{I} / 02 / \mathrm{IO} /$ yanvarskie-protesty/. Access on Feb. IO, 202I. 
Navalny has a tendency to continue to increase his presence on the political scene in Russia. However, he will have to overcome the legal difficulties imposed by his conviction, in addition to the ghosts of his ultranationalism that are often revived, and, more importantly, he will need to assert the image promoted by the Western media and become in fact the leader of such a diffuse and disorganized opposition, corresponding to the inflated popularity attributed to it. All of this, in view of the great popularity of Putin, who, having suffered ups and downs, does not seem to be significantly eroding, not even during the difficult months of the pandemic and the long period of economic difficulties under the pressure of sanctions.

\section{Another Crisis on Ukraine's Borders}

Rodrigo Ianhez ${ }^{12}$

The dispute between Ukraine and the self-proclaimed People's Republics of Donetsk and Lugansk is another one of those military conflicts that, after dominating the news for months, fall into oblivion, despite being far from a resolution. At the end of March 202I, hostilities show signs of intensification, after a period of relative calm $^{13}$, and as usual, the parties accuse each other of escalating the situation. It is not a coincidence that this occurs after a series of discussions at the beginning of this year about the legislation that regulates the Ukrainian citizenship regime.

The issue of citizenship has been unfolding since 20I4, when after reclaiming the Crimean peninsula, Russia started a program that distributed millions of passports to citizens of the Autonomous Republic that previously belonged to Ukraine. The situation has become even more complex with the virtual independence of the separatist regions of Donbass and the growing search of the locals for the Russian passport. According to the current Ukrainian constitution, Ukrainian citizens are not allowed to have more than one citizenship. In practice, this rule does not apply and millions of Ukrainian citizens have multiple citizenship. In 2020 alone, about 400,000 citizens of Ukraine obtained passports from the Russian Federation, after the Kremlin adopted measures that simplified obtaining Russian citizenship ${ }^{\mathrm{I}}$, totaling

I2 Historian from Moscow State University.

I3 Interfax.ru. 2021. “Песков отметил нагнетание напряжения на линии соприкосновения в Донбасcе”. Interfax, March 30, 202I. https://www.interfax.ru/ world/758539. Access on Mar. 31, 2021.

I4 Tickle, Jonny. 202I. "Following Moscow's move to liberalize citizenship process, more than 400,000 Ukrainians received Russian passports in 2020”. RT News, January 28, 2021.https:// 
more than $60 \%$ of passports issued in the period by Russia ${ }^{15}$. In addition, hundreds of thousands of Ukrainians from the western regions of the country have Hungarian, Slovak and Polish citizenship.

In January of this year, deputies of the Servant of the People, to which President Volodomyr Zelenski belongs and which bears the name of the television series that catapulted him to power, filed a bill that seeks to change the rules of multiple citizenship in Ukraine. The project envisages allowing Ukrainian citizens to obtain multiple citizenship, but imposes a series of restrictions on those who have dual citizenship in an "aggressor country". In 20I8, Rada, the Ukrainian parliament, passed a law that attributes the status of an aggressor country to the Russian Federation. In addition to banning such citizens from taking public service posts, running for or even voting in the Ukrainian elections, the new law would impose two to five years in prison for those who concealed dual Russian citizenship.

The ban on voting for citizens with dual Russian citizenship in Ukrainian elections is vital for the authorities in Kiev, who see potential ethnic traitors in the ethnically Russian citizens, such as the separatist rebels. It is no coincidence that such a discussion occurs in parallel with the growing popularity of the pro-Russian forces, organized in the Platform of Opposition - For Life party. This March, opinion polls pointed to a technical tie in a presidential race between Zelensky and pro-Russian leader Viktor Medvedchuk ${ }^{\mathrm{i}}$. The opposition has been suffering an open offensive by the Ukrainian government that forced the opposition media to end its activities at the beginning of the year. Medvedchuk himself is under investigation by the Ukrainian security apparatus on charges of supporting separatist terrorist groups.

In recent statements, the Minister of Foreign Affairs of Ukraine, Dmitri Kuleba, raised the possibility of simply banning Ukrainian citizens from having dual citizenship with Russia. He said that a project is under negotiation with Rada for which Ukrainians would be allowed to obtain passports from countries in the European Union and other "friendly" countries, but ruled out the possibility of authorizing dual citizenship with "aggressor countries" ${ }^{17}$.

www.rt.com/russia/5138I3-passports-statistics-citizenship-process/. Access on Jan. 28, 202I

I5 Gazeta Daily.ru. 202г. “Тюрьма и поражение в правах: что грозит владельцам паспортов РФ на Украине”. Gazeta Daily, January 29, 2021. https://www.gazeta.ru/ politics/202I/OI/29_a_I3459724.shtml. Access on Jan. 29, 202I.

I6 UNIAN. 202I. "Election runoff in Ukraine would see Zelensky, Boyko - Poll". UNIAN Information Agency, March 03, 202I. https://www.unian.info/politics/popular-ratings-electionrunoff-in-ukraine-would-see-zelensky-boyko-poll-ıı366I97.html. Access on Mar. 03, 2021.

I7 RBC.ru. 202I. “Глава МИД Украины исключил двойное гражданство с Россией”. RBC, March 05, 202I. https://www.rbc.ru/politics/05/03/202I/604If3699a7947833e889oif. 
It remains to be seen whether the government in Kiev will be able to maneuver the parliament to pass measures of constitutionality so debatable. It is clear that the interests behind such measures are in containing Russian influence over the country, which grows as the Euromaidan project increasingly shows signs of bankruptcy and Ukraine sinks as the second poorest country in Europe.

\title{
Hong Kong's Demonstrations in 2019-2020
}

\author{
José Miguel Quedi Martins ${ }^{18}$ \\ Bruno Magno $^{\text {I9 }}$
}

In this article we seek to address the events that took place in Hong Kong between February 20I9 and June 2020, situate their context, and carry out a preliminary assessment as a conclusion.

The Facts - In February 2019, a bill, proposed by the Hong Kong government, was introduced to hand over to Taiwan an individual accused of murder $^{20}$. On March 3I, 20I9, demonstrations exploded demanding the withdrawal of the project, allegedly for threatening civil rights and the autonomy of the city. Unlike what had happened with the protests in $2014 \mathrm{i}^{2 \mathrm{r}}$, this time the movement enjoyed broad popular support.

As a result, on June I5, 2019, the bill was withdrawn and suspended from voting indefinitely. Even so, the next day, the largest demonstration took place - two million participants were estimated - which, if confirmed, is extraordinary, given that the entire region has seven million inhabitants.

The organizers could have considered that the demonstration on June I6, 2019, had been an apotheosis, the celebration of victory, the expression that the last word - and action - had come from the movement. Instead, they decided to continue with the demonstrations, this time with the aim to overthrow the government of Carrie Lam.

Access on Mar. 05, 202I.

I8 Professor of International Relations at UFRGS. Researcher at NERINT.

I9 PhD Candidate in Political Science (PPGCP/UFRGS). Researcher at NERINT. brunomgn@ gmail.com/bruno.magno@ufrgs.br

20 Subsequently, it was proposed that the project should include - in addition to Taiwan - also Mainland China and Macau.

2I Umbrella Movement - Protests that broke out in Hong Kong in 20I4 against the submission of the list of candidates to the Hong Kong executive for Beijing's approval. The name of the movement is due to the protesters use of umbrellas to protect themselves from objects thrown from the buildings. 
This caused the waning of popular support to the movement. As the volume of demonstrations had decreased, the organizers intensified the confrontations - including clashes between protesters, widespread depredations and even attacks on police stations.

On May 2I, 2020, the Beijing National People's Congress announced the drafting of a law against foreign interference, secession, and terrorism. The then US Secretary of State Mike Pompeo and the Secretary of Foreign Affairs of the United Kingdom, Dominic Raab, announced that their approval would mean the end of Hong Kong's autonomy ${ }^{22}$. Stimulated by the support obtained from abroad, the protests had a new impetus and, progressively, a secessionist feature.

Then, on June 30, 2020, the Beijing National People's Congress unanimously passed a national security law with effect in Hong Kong. Only then did the police obtain a legal basis to crack down on protesters and their organizations. On July 3I, 2020, the postponement of the elections was announced, and twelve candidates were disqualified and barred from running.

The city, exhausted by sixteen months of daily confrontations, was finally pacified. The movement came to an end without the intervention of Beijing's tanks - eventually frustrating those who expected to see the reissue of the tragic events of Tiananmen (I989).

The Context - The Hong Kong demonstrations seem to signal the exhaustion of the model put in place with the Arab Springs that started in Tunisia in 20I0. At that time, the movement immediately made itself felt over China, with the protesters adopting the same name, the Jasmine Revolution (02/20/20II to 03/20/20II).

The Chinese Jasmine Revolution took place months before the official announcement of the "Pivot to Asia". Originally suggested by the publication of Hillary Clinton's article on October II, $20 \mathrm{II}^{23}$, and made official by Barack Obama's speech in Darwin in Australia on November I7, 20II. It was a question of expressing a willingness to "contain" China - which, in practical terms, means promoting regime change.

The effectiveness of the seemingly fledgling Chinese spring of 2OII can be measured by the reaction triggered against it. In 20I2, due to

\footnotetext{
22 One Country, Two Systems - Principle formulated by Deng Xiaoping in the early I980s, to allow a peaceful reunification of China with its territories (Macau, Hong Kong and Taiwan). The formula provided for the maintenance of capitalism in these regions, which would also enjoy remarkable administrative autonomy. It is important to note that at that time there was no democratic regime in any of these regions.

23 Clinton, Hillary. 20II. "America's Pacific Century: the future of geopolitics will be decided in Asia, not in Afghanistan or Iraq, and the United States should be right at the center of the action". Foreign Policy, n. I89, p. 56-63, Nov. 2011.
} 
the dispute over the Diaoyu/Senkaku Islands ${ }^{24}$, there was an explosion of nationalism in China, expressed in strong anti-Japanese disturbances (19/08 / I2-I9 / 09/I2). They cut short the days of Hu Jintao's rule - and, in Japan, overthrew the government of the pro-China's Democratic Party of Japan - and brought up a shabby Maoism, disguised as chauvinism, swept away the hope of structuring an East Asia Community 25.

Next was the rapprochement process with Taiwan, which has been ongoing since 2008. It had already promoted on a large scale the free circulation of factors of production (people, goods and capital) between the two sides of the strait. But then came the Sunflowers Movement in Taiwan (03/I8/I4 - 04/10/I4) undertaken by a minority of overt pro-Taiwan Independency supporters of Tsai Ing-wen. The highlight of the Movement of the Sunflowers was the occupation of parliament. Despite the notorious illegality and vandalism, the action had close support from the local and international media. Thus, it was possible to hijack the consensus, hitherto dominant in public opinion, favorable to the cross-strait rapprochement. Tsai then pursued a policy of reversing investments and relocating industrial enterprises to Southeast Asia.

The Chinese response came in May 20I5, with the launch of the "Made in China 2025" plan. The country only produced that year I6\%of the semiconductors it used. The ambitious plan intended to lead the Chinese to produce $40 \%$ by 2020 , and $70 \%$ by $2025^{26}$. Henceforth, the decisive commodity of the new Industrial Revolution would become the object of international dispute. And, as a result, an element that would tension the reconcentration of production and the reterritorialization of historical capitalism.

As empirical evidence of these trends, there is the Trade War between South Korea and Japani ${ }^{27}$. Also included is the addition of the semiconductor agenda, due to Huawei, in the trade war between China and the United States, just when it seemed to have already cooled down towards a preliminary agreementi $^{28}$.

24 Diaoyu/Senkaku Islands - Five uninhabited volcanic islands, located I7o kilometers from Taiwan. Controlled by Japan and claimed by Taiwan and China.

25 East Asian Community - Formula used by the Ministry of Foreign Affairs of Japan, starting in 2009 , to designate a finalistic purpose of the trilateral summits held between Japan, China and South Korea.

26 Lewis, James A. 20I9. Learning the Superior Techniques of the Barbarians: China's Persuit of Semiconductor Independence. Washington, DC: CSIS, 20I9. pp. oI-02.

27 Korea-Japan Trade War - Started in October 2018 due to a South Korean local court ruling on compensation for "comfort women", one of Japan's war crimes. In response, Japan passed in July 2oIg to boycott the supply of semiconductors to South Korea.

28 China-US Trade War - Started in 20I8, it was waged for the purpose of reducing the US 
In addition to the obvious departure from China, the net result of the Sunflower Movement was to deprive Taiwan of its "Great Silicon Wall", that is, of the technological dependence that China had on the island for highly miniaturized semiconductors. The move was not exempt from costs. In Singapore, Taiwan Semiconductor Manufacturing Company (TSMC), the Taiwanese semiconductor giant, collapsed the main local company, Chartered Semiconductor Manufacturing (CSM) - which ended up being controlled by an association of businessmen from the United Arab Emirates and the United States. Predictably, Southeast Asia cannot absorb the new supply of microelectronics companies. Thus, TSMC announced the construction of its largest semiconductor factory in a standard of five nanometers $(5 \mathrm{~nm})$ in the $\mathrm{US}^{29}$.

Between April I5 and I6 of 202I, the first official visit of the Japanese Prime Minister Suga was made to US President Joe Biden. At the end of the summit, Japan announced a commitment to invest $\$ 2$ billion in the US semiconductor industry ${ }^{3 \circ}$. On the same occasion, the United States and Japan declared that it is imperative that China and Taiwan resolve their disputes peacefully $y^{35}$. To which China replied, "We urge the United States and Japan to take China's concern seriously, obey the principle of one China and immediately stop meddling in China's internal affairs and harm China's interests"32.

Preliminary Assessment - The US has undoubtedly won. They took two billion Japanese dollars and the largest and best semiconductor plant of

trade deficit. In May 20I9, Trump resolved to securitize the problem with banning Huawei and boycotting the supply of semiconductors to China. In January 2020, Beijing conceded, reaching a preliminary agreement that China has pledged to buy $\$ 200$ billion more in American products. However, due to pending issues involving executive orders and subsequent sanctions against Chinese companies, the dispute has not ended clearly until today.

29 Bajarin, Tim. 202I. "Why TSMC's Arizona Fab Is Strategic For Tech's Future In The US". Forbes, Februeryi6, 202I. https:/www.forbes.com/sites/timbajarin/202I/O2/I6/why-tsmcsarizona-fab-is-strategic-for-techs-future-in-the-us/?sh = Ie77535IIc8a. Access on Apr. 20, 202I.

30 Brunnstrom, David; et al. 2021. “Biden and Japan's Suga project unity against China's assertiveness". Reuters, April I7, 202I. https://www.reuters.com/world/china/biden-welcomejapans-suga-first-guest-key-ally-china-strategy-202I-04-I6/. Access on Apr. 20, 202I.

3I WHITE HOUSE. 202I. “USA; Japan. US- Japan Joint Leaders' Statement. US-Japan Global Partnership For A New Era”. WHITE HOUSE, April I6, 202I. https://www.whitehouse.gov/ briefing-room/statements-releases/202I/04/i6/us-japan-joint-leaders-statement-us-japanglobal-partnership-for- a-new-era /. Access on Apr. 20, 2021.

32 China. 202I. “China. Foreign Ministry Spokesperson's Remarks on Negative Content Concerning China in US-Japan Joint Leaders' Statement”. China Foreign Ministry, April I7, 202I. https://www.fmprc.gov.cn/mfa_eng/xwfw_665399/s25IO_66540I/2535_665405/ tI869625.shtml. Access on Apr. 20, 2021. 
Taiwan. Both gains will serve to rebuild its infrastructure and industrial base. China also stands out as a winner: it obtained the effective reintegration of Hong Kong and it will add to the "Made in China 2025" plan the facilities in its territory of TSMC and Singaporean CSM. Although one can see the event of a war for Taiwan, this possibility is by no means new. Japan, for instance, produced the "bait and bleeding" 33 strategy between the US and China, but with no visible success. Finally, Taiwan and Hong Kong stand as the biggest losers. The first found itself stripped of its "silicon wall". The latter has lost the most democratic system of government in its history.

\section{Vaccine Diplomacy or Vaccine Nationalism?}

Guilherme Thudium ${ }^{34}$

On December 2, 2020, the United Kingdom became the first country to approve a covid-I9 vaccine. It was an important milestone in the battle against the novel coronavirus, which, however, is still far from over. Logistically, it was just the beginning. The developed countries of the North Atlantic, especially the United States and the United Kingdom, which possess the technology and the best infrastructure conditions, took the lead, focusing on vaccinating their own populations and imposing export controls, a process that threatens immunization in the underdeveloped world.

Logistics is an important concept in the realm of Strategic Studies, an interdisciplinary field that studies how actors in the international system use military means to achieve political goals. Logistics is, therefore, originally a military enterprise, or, in the words of the Igth century French-Swiss general Antoine-Henri Jomini35, "the practical art of moving armies". In fact, until the end of World War II, the concept was associated with military activities in the preparation for war, following the terms offered by Carl von Clausewitz, the Prussian general who best operationalized the concept for Strategic Studies,

33 Bait and Bleeding - "This strategy involves causing two rivals to engage in a protracted war so that they bleed each other out while the baiter remains on the sidelines, with its military strength intact" (Mearsheimer, John J. 200I.The Tragedy of the Great Power Politics. New York: W.W. Norton \& Company).

34 President of the South American Institute for Policy and Strategy (ISAPE) and member of the Center of German and European Studies (CDEA) at UFRGS and PUC-RS.

35 Jomini, Antoine-Henri. 2005. The Art of War BY Baron de Jomini, General and Aide-DeCamp of the Emperor of Russia. Special Edition. El Paso: El Paso Norte Press. 
even though he did not address it directly ${ }^{36}$.

It was only from the I980s onwards that logistics was effectively expanded to the mainstream notion of a civilian structure aimed at jointly coordinating complex operations of planning, implementing and controlling the flow and efficient storage of goods and services - an appropriation that is still contested by more orthodox strategists. In any case, the distribution of the covid-I9 vaccine to the entire world population will be the largest and most complex logistical operation in history, and it will also require the involvement and preparation of national Armed Forces.

The vaccine first approved in the United Kingdom from German biotechnology company BioNTech and American pharmaceutical corporation Pfizer, for example, has been described as a "logistical nightmare". In addition to the challenges of large-scale distribution, it needs to be stored at very low temperatures, which may make it infeasible for some countries in the developing world. Many regions of the Geopolitical South still face serious problems with basic infrastructure, such as electricity, roads, railways, potable water and integrated information and communication services.

The slow production and distribution around the globe has once again put the United Kingdom in shock with the countries of the European Union (EU), largely due to delays in the export schedule of the AstraZeneca vaccine, which prioritized the national demand following requirements of the British government. EU member countries - traditionally a major exporter of immunizing agents -, in turn, announced export bans, including 250,000 doses that would be exported to Australia, a traditional ally of the developed axis of world powers ${ }^{37}$. Thus, in the current scheme of things, vaccination will not reach the Third World widely before 2023 (Figure I).

36 Proença, Domício, and E. E. Duarte. 2005. "The Concept of Logistics Derived from Clausewitz: All That Is Required so That the Fighting Force Can Be Taken as a Given". Journal of Strategic Studies 28, no. 4 (2005): 645-77. https://doi.org/I0.1080/01402390500301046.

37 Visentini, Paulo. 20I9. Eixos do Poder Mundial no Século XXI: uma proposta analítica. AUSTRAL: Revista Brasileira de Estratégia e Relações Internacionais, 8(I5). doi: https://doi. org/I0.22456/2238-6912.9I767. 


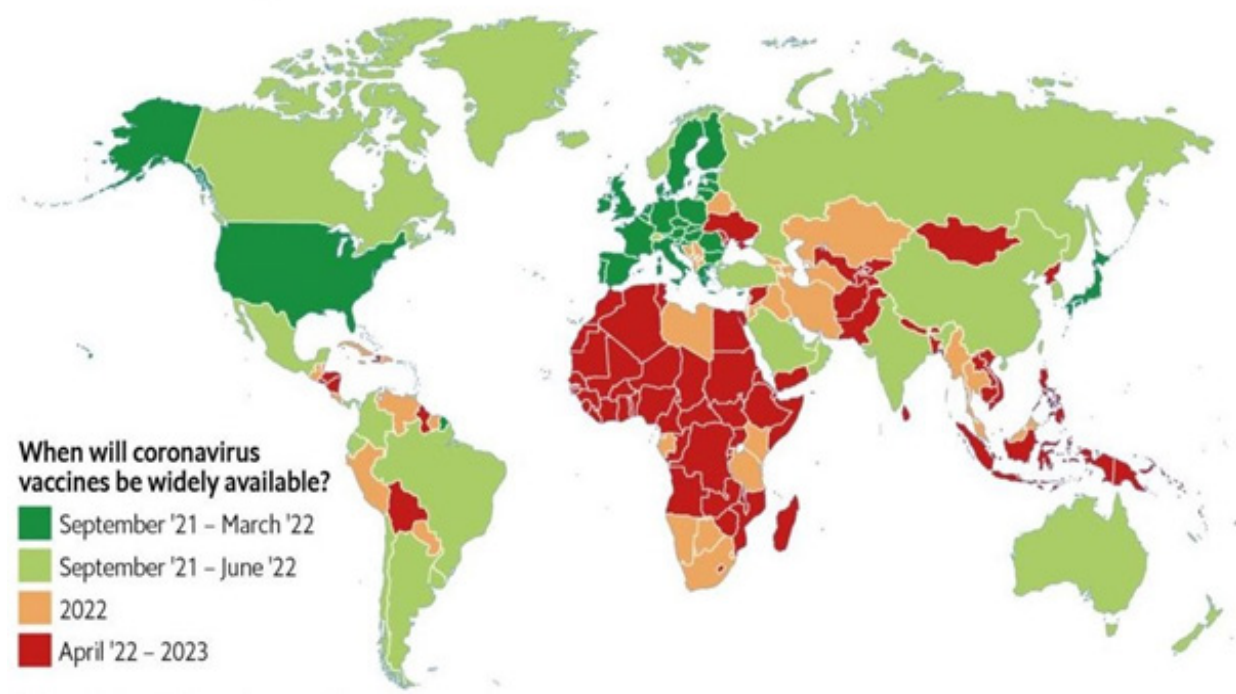

\section{Source: The Economist Intelligence Unit (2021) $3^{38}$.}

The promise of fair access, therefore, is at serious risk, which represents a moral failure in terms of widespread vaccination and will only prolong the pandemic, the necessary restrictions for its control and human and economic suffering, as was recognized by the World Health Organization ${ }^{39}$. By allowing the virus to proliferate in the developing world, especially in countries that have not been successful in containing the novel coronavirus, the world is allowing room for new mutations that could impair the vaccination process that is being carried out in the developed world, requiring constant updates of the formula and calibration of expectation.

On February I7, 202I, the Secretariat of Foreign Affairs of Mexico, represented by Minister Marcelo Ebrard, filed a formal complaint at the United Nations Security Council meeting on the unequal distribution of the covid-I9

38 The Economist Intelligence Unit. 2021. "More than 85 Poor Countries Will Not Have Widespread Access to Coronavirus Vaccines before 2023". The Economist, February I9, 202I. https://www.eiu.com/n/85-poor-countries-will-not-have-access-to-coronavirus-vaccines/. Access on Feb. I9, 2021.

39 WHO. 202I. "WHO Director-General's Opening Remarks at I48th Session of the Executive Board". World Health Organization, January I8, 202I. https://www.who.int/director-general/ speeches/detail/who-director-general-s-opening-remarks-at-I48th-session-of-the-executiveboard. Access on Jan. I8, 202I. 
vaccine around the world. At that time, Mexico had the highest number of deaths per million inhabitants in Latin America, according to Johns Hopkins University ${ }^{40}$. A few days later, WHO finally operationalized the Covax initiative, an international cooperation venture aimed at expanding global access through the Indian Covaxin vaccine. On February 24, 202I, the first doses of the initiative arrived in Ghana, in the Gulf of Guinea. Brazil is among the five countries that will receive the largest amount of doses from the Covax consortium, according to the organization.

In the opposite direction of vaccine nationalism, the countries that make up the BRICS grouping are leading a process of "vaccine diplomacy". India is already the world's biggest vaccine manufacturer, while Russia was the first country to register a covid-I9 vaccine, Sputnik V, which is being used by many Latin American countries. China is already building a global distribution network for its vaccine, the so-called "Health Silk Road", with the aim of improving its global reputation. The BRICS New Development Bank (NDB) has allocated US\$ Io billion to fight the pandemic, of which US\$ 2 billion are destined for Brazil. The first half of the amount was delivered to the Brazilian government in February $202 \mathrm{I}^{4 \mathrm{I}}$.

South Africa and India also pleaded at the Council on Trade-Related Aspects of the World Trade Organization (WTO), in October 2020, a patent waiver on covid-I9 vaccines in order to increase production capacities of immunizers in developing countries. The proposed TRIPs Agreement (Agreement on Trade-Related Aspects of Intellectual Property Rights) has since been co-sponsored by Kenya, Eswatini, Mozambique, Pakistan, Bolivia, Venezuela, Mongolia, Zimbabwe, Egypt, the African Group and the group of Least Developed Countries (LDC) ${ }^{42}$.

The United States, under the Biden administration, reversed its initial position and announced support for the covid-I9 vaccine patent waiver in May, 202I. European countries, however, have not followed suit. Germany, the region's main center of gravity, is the owner of a thriving pharmaceutical

40 Johns Hopkins University. 202I. “COVID-I9 Map”. Johns Hopkins Coronavirus Resource Center, 202I. https://coronavirus.jhu.edu/map.html.

4I Núcleo Brasileiro de Estratégia e Relações Internacionais (NERINT). 202I. "Brasil recebe R\$ 5 bilhões do Banco dos BRICS para combater o coronavírus”. Núcleo Brasileiro de Estratégia $e$ Relações Internacionais, February I2, 202I. https://www.ufrgs.br/nerint/brasil-recebe-r-5bilhoes-do-banco-dos-brics-para-combater-o-coronavirus/. Access on Feb. I2, 202I.

42 WTO. 2020. "Waiver From Certain Provisions of the TRIPS Agreement for the Prevention, Containment and Treatment of Covid-I9 (IP/C/W/669)". Geneva: Council for Trade-Related Aspects of Intellectual Property Rights, World Trade Organization, October 02, 2020. 
industry and, for the moment, is opting to protect its economic interests, following the traditional precepts of its protectionist model of capitalism.

Considering the unprecedented levels of interconnection and globalization seen today, the response to contemporary challenges must be broad-spectrum, that is, concerted multilaterally. The challenge will always be global, and never just national, and international cooperation is therefore essential. International, regional and domestic institutions, including the Armed Forces, will play an important role for effective global and logistical action to overcome the pandemic through mass vaccination - the only way for the responsible resumption of economic activity worldwide.

The covid-ig vaccine must be seen as a global common good, and the different needs and capacities of developing countries need to be considered when formulating the strategy of this grand logistical enterprise, since not all countries are inserted in the international system on an equal footing. In times of crisis, multilateralism, integration and diplomacy show their importance, and countries whose diplomatic tradition is based on universalism, as is the case in Brazil, could benefit. But, for that, foreign policy needs to be constructive and pragmatic, rather than ideological.

\section{The Coup in Myanmar and its Geopolitical Consequences for Asia}

In February 202I, after ten years of relative stability, the young democratic regime in Myanmar was interrupted by the military's seizure of power. The intervention of the armed forces - the Tatmadaw - took place on allegations of fraud in the general elections, which yielded a massive victory for the National League for Democracy (NLD), led by Nobel Peace laureate Aung San Suu Kyi. As in I988, several political leaders were arrested - among them Suu Kyi - and protests emerged with violent suppression by security forces, causing hundreds of deaths in a few weeks. Older problems experienced by the country add to this context, such as the social conflict involving the Rohingyas and several native paramilitary groups that have risen up against the Burmese majority government since independence in 1947.

The chaotic scenario in the middle of the covid-I9 pandemic raises several questions about the motivations of the political actors involved and

$43 \mathrm{PhD}$ in International Strategic Studies (Federal University of Rio Grande do Sul, UFRGS). 
their external alignments: Myanmar has been the object of a dispute between the United States and China since the democratic opening. This brief article points to possible implications of political instability in Myanmar for the whole region, as the focus of geopolitical competition in recent years has been shifting towards Southeast Asia and South Asia. These two sub-regions are considered to be the fragile periphery of China and India, where patterns of cooperation and conflict have direct consequences for the internal security of both countries. Myanmar is located at the intersection between the two sub-regions, seen both as a potential hub for regional integration, a buffer of security isolation or a stage of external interference to undermine the security of its' giant neighbors peripheries ${ }^{44}$.

Afterindependence, Myanmar (then Burma) always preferred neutrality in its foreign policy, which turned into isolation after the establishment of a socialist civil-military regime in I962. The choice was made precisely to avoid the dynamics of the Cold War in a context of domestic fragility. Only two thirds of the population are of Burmese ethnicity and the other 33\% are divided into several ethnic groups that occupy regions bordering China, India, Laos and Thailand. These ethnicities had been armed by the Allies - the United States and the United Kingdom - in order to fight Japan in World War II, but they maintained their troops to fight the new government set after British colonization ${ }^{45}$. Despite several attempts at military victory and political co-optation of these groups, no government in Myanmar has managed to establish even a universal ceasefire.

At the end of the I980s, the socialist regime collapsed and made room for an accelerated and disorganized process of democratization. In the face of the sudden loss of political power and the overwhelming victory of the NLD and Suu Kyi, the military struck a coup in I988 to establish a provisional government junta. The post-Cold War total isolation, along with Western and Japanese sanctions were only relieved by the partnership with China and the diplomatic support of Russia and ASEAN (Association of Southeast Asian Nations).

Myanmar remained an international pariah until announcing its re-democratization with a new constitution in 2008 and elections in 2010. However, the NLD boycotted the election due to the government's institutional

44 Ribeiro, Erik H. 20I5. A rivalidade e a cooperação nas relações China-Índia: o contexto asiático e o caso de Mianmar. 226 f. PPGEEI, UFRGS: Porto Alegre.

45 Some of these paramilitary groups even entered the businesses of opium cultivation and drug trafficking, allying themselves with troops from the Chinese Kuomintang Army, who fled in 1949 to northern Burma after the defeat in the Chinese civil war. 
format, which kept the military in the role of caretaker of the new regime ${ }^{46}$. From 20Io, the military and Aung San Suu Kyi reached a political agreement, encouraged by China and the United States. The power sharing arrangement was based on liberalization and economic opening to the outside, while the key issues of internal and external security remained under the command of Tatmadaw.

At first, the government of President Thein Sein (20II-20I5), a retired general of the reformist wing, signaled a movement towards rapprochement with Washington, canceling two large Chinese projects after popular pressure: the Myitsone hydroelectric plant (which would become one of the world's largest dams) in 20II and the Rakhine-Yunnan railway in 20I4. Both projects are central to the policy of economic projection of the Chinese countryside (particularly the Yunnan province) via Indian Ocean. Despite this, the gas and oil pipeline projects linking Myanmar to China were completed during this period. For this reason, Myanmar has been called the "Chinese California", in reference to the bioceanic access that China would gain with the complete logistical integration to the neighboring country.

After the NLD's victory in 20I6, Suu Kyi was appointed State Councilor, becoming the de facto leader of the government. During her tenure, Suu Kyi faced severe international criticism, as she had to defend the country against denunciations of human rights violations of the Rohingyas. This group originally came from East Bengal (now Bangladesh) and migrated to Burma during British colonization, but its citizenship rights are not recognized by either country47. Since 20I2, social uprisings between Buddhists and Muslims in the state of Arakan have revived the ethnic conflict, spawning new revolutionary paramilitary groups (such as the Arakan Rohingya Salvation Army), now funded by fundamentalist Rohingya networks based in Pakistan and Saudi Arabia. In 2019, Myanmar was charged for genocide at the United Nations International Court of Justice, where the case remains under analysis.

Faced with diplomatic pressures, the young democratic regime in Myanmar suffered again in the search for international normalization. Previously, the withdrawal of economic sanctions had attracted Western and Japanese investments, which carried out a race with China for contracts for the exploitation of natural resources, construction of infrastructure, logistics and digital services, among others. In 20I8, after successive crises involving

46 According to the 2008 Constitution, the Tatmadaw appoints $25 \%$ of the members of parliament, chooses one of the two vice-presidents and also the ministers of defense, home and border affairs. In addition, constitutional amendments require $75 \%$ approval from the two parliamentary houses, conferring effective veto power to the military.

47 Historically, the Burmese government had already tried to expel this population and mujahideen insurgent groups on two occasions (I978 and I99I-92), but was unsuccessful. 
the Rohingyas, Myanmar's Foreign Direct Investment (FDI) inflows fell dramatically and the country lost Western diplomatic support. Then US Vice President Mike Pence publicly criticized the Suu Kyi government during a visit to the country and the European Union's Investment Protection Agreement negotiations with Myanmar were canceled.

Suu Kyi, who maintained good relations with both Beijing and Washington during her term, tried a pragmatic approach in this scenario of looming isolation. In 20I8, Myanmar agreed to sign the China-Myanmar Economic Corridor (CMEC) project, which could become comparable to the China-Pakistan Corridor (CPEC), the largest pillar of the Belt and Road Initiative (BRI). A series of railways is expected to connect Kunming (the capital of Yunnan) to Kyaukpyu, on Myanmar's coastline, where a deepwater port is being built by Chinese companies. In January 2020, Suu Kyi received a visit from Xi Jinping, the first by a Chinese head of state in I9 years, signaling good relations between the two countries and advancing yet another series of BRI agreements. Despite this, the constant confrontation between paramilitary groups and the Tatmadaw has threatened Chinese projects in the country, which are being criticized and targeted by part of the local communities. In addition, there are illegal arms and gem trafficking businesses in northern Myanmar, which are carried out by Chinese organized crime networks with the help of local militias.

The February 202I military coup was met with surprise, as there were few public signs of the silent power struggle between Suu Kyi's group and the military. Behind the scenes, the personality cult of the "Lady", as she was called derisively by the generals of the junta, has become a threat to the political survival of the military. In addition to potential popular pressure for the elimination of their veto power, military elites fear that their economic power will be progressively opposed by a hostile government: Most national companies in all sectors are controlled by conglomerates of military families, who are often targets of external pressure and sanctions. The fact that Suu Kyi waged on her Buddhist identity - in order to win the support of nationalist sectors of the population - also bothers the military, who have lost their electoral viability. More than that, there are criticisms from foreign colleagues and diplomats about her management style inside the NLD, seen by some as clientelist and personalist ${ }^{4}$.

From a local and regional point of view, there are several relevant

48 Charney, Michael W. 202I. Keynote Address: A Historian Considers the Current Military Takeover in Myanmar. Myanmar Dialogues Conference. Mueang Phitsanulok: Naresuan University. Available at: https://www.researchgate.net/publication/34925I753_A_Historian_ Looks_at_the_Ongoing_Takeover_in_Myanmar_Keynote_Address_for_Myanmar_Dialogues_ Conference_at_Naresuan_University 
repercussions for the coming years. First, China tried to open dialogue between the parties, but was unsuccessful due to Suu Kyi's refusal to meet the military's demands for the preservation of the spirit of the 2008 Constitution: a democracy guided by the Tatmadaw ${ }^{49}$. On the contrary, part of the popular uprising has turned not only against the military and their companies, but also against Chinese businesses spread across the country, especially in the former capital Yangon. The Chinese are at risk of having their image increasingly associated with the military regime and, thus, hampering their geo-economic plans in the country and the global image of the New Silk Road.

The coup also divided opinions among ASEAN countries, which alternated between criticism, indifference or tacit support for the military regime. Countries like Thailand (which periodically faces military coups and has been governed by a provisional junta for five years), Cambodia and Laos have adopted a stance close to that of China, defending Myanmar's sovereignty and opposing external sanctions. On the other hand, ASEAN leaders Indonesia, Malaysia and Singapore - criticized the institutional breakdown in Myanmar, urging a quick return to the rule of law, also because of the concern of the first two countries with the situation of the Rohingyas. The coup also divided the Philippines, which experienced long autocratic regimes in the past and is currently governed by Rodrigo Duterte, a conservative leader with authoritarian inclinations ${ }^{50}$.

In general, the coup in Myanmar has led to comparisons with Syria by the Western media, mainly due to persistent mass protests, civil disobedience, the joining of paramilitary minority groups and the violent suppression of the movement by security forces ${ }^{5 \mathrm{I}}$. As in the so-called "Arab Spring" and in Afghanistan, there is fear that the situation in Myanmar will become an exporter of instability to the neighborhood. It is important to note that Tatmadaw is a cohesive institution and rooted in all spheres of society in its boss-client relations, including among a good part of ethnic minorities. Second, it is not in the interest of any of the neighbors to see a process of balkanization in Myanmar, since China and India have their own concerns vis-à-vis national minorities on these borders. Third, there is no external mobilization for direct or indirect external interventions as occurred in Libya and Syria, and some of the main paramilitary groups in northern Myanmar

49 Ibidem.

50 Heydarian, Richard J. 202I. "Myanmar's coup splits an already deeply divided region". Asia Times Online, Februry 05, 202I. https://asiatimes.com/2021/02/myanmars-coup-splits-analready-deeply-divided-region/. Access on Apr. 08, 2021.

5I Tisdall, Simon. 202I. "Is Myanmar the new Syria? Rising violence threatens a repeat tragedy". The Guardian, April 04, 202I. https://www.theguardian.com/commentisfree/202I/apr/04/ismyanmar-the-new-syria-rising-violence-threatens-a-repeat-tragedy. Access on Apr. 04, $202 \mathrm{I}$. 
are in fact sustained with Beijing's complicity ${ }^{2}$.

Although a spiral of chaos at the national level is a less likely scenario, there are reasons to believe in a prolonged political stalemate. Immediately after the coup, the provisional regime promised to restore institutional normalcy within a year and call for new elections. Unlike the Thai military, the Tatmadaw has not suspended the current constitution and is trying - at least publicly - to defend the legality of its actions. However, NLD lawmakers, bureaucrats and dissident activists have announced the creation of a government in exile (Committee Representing Pyidaungsu Hluttaw, CRPH). The Committee's objective is to propose a new federal charter and replace the 2008 Constitution, abolishing military privileges and constituting new federal armed forces. The Committee recently received support from some political and paramilitary groups among ethnic minorities, while others warned the Tatmadaw that they could abandon ceasefire agreements in favor of dissidents ${ }^{53}$.

The return to normality will essentially depend on renegotiation with Suu Kyi and the NLD, which will involve some degree of diplomatic accommodation between China and the United States. At this moment, Biden's strategy has been to form an "anti-authoritarian" front among American allies: in Myanmar, the solution found was direct sanctions against the military, their families and part of their companies, along with the freezing of the national government's assets in the United States. Still, Biden's strategy appears to be much more lenient than pressures exerted against other countries in the recent past, as in the case of Iran ${ }^{54}$. In addition to domestic challenges, Myanmar will be an important test in relations between the Xi Jinping government and the new Biden administration.

52 Myers, Lucas. 202I. "Myanmar Is on the Precipice of Civil War". Foreign Policy, April o8, $202 \mathrm{I}$. https://foreignpolicy.com/202I/04/08/myanmar-military-coup-ethnic-armed-organizationscivil-war/. Access on Apr. ०8, 202I.

53 Ibidem.

54 Samet, Andrew. 2021. “Myanmar and Biden's Broken-Down Car Dilemma”. The Diplomat, February 22, 202I. https://thediplomat.com/2021/02/myanmar-and-bidens-broken-down-cardilemma/. Access on Feb. 22, 202I. 


\section{Days: Biden's Foreign Policy}

Cristina Soreanu Pecequilo55

The first hundred days of any United States (US) President in office are defined as a "honeymoon" amongst the White House, the press and political forces of opposition, to assure a peaceful and stable transition of power. In 202I, neither of these conditions can be applied to democrat Joe Biden's mandate, as a result of the social-economic crisis and the ongoing polarization. Apart from this scenario, the presidency is forwarding its agenda. When it is not possible to govern by consensus (as in the approval of the economic aid package of U\$ I,9 trillion), the option is to issue Executive Orders that allow to fast advance legislation and implement decisions without having to deal with Congress. This is a very frequent path, leading to the dismantling of the Trump era. Based on this reality, the analysis of foreign policy in the first hundred days can be divided into three parts: the profile of the government team, the first strategic documents and the practical experience.

Whereas considering the international relations key names, critics sustain that Biden's tenure is somewhat a Obama III government, repeating its interventionist, pro-regime change and expansionist stance. This is not an erroneous assertion and the team itself is keen to present this continuity: Secretary of State- Antony Blinken, National Security Adviser- Jake Sullivan, US Ambassador to the United Nations- Linda Thomas Greenfield, Secretary of Defense- Lloyd J Austin III, Secretary of Treasury- Janet Yellen, United States Trade Representative (USTR)- Katherine Tai, United States Agency for Aid and Development (USAID)-Samantha Power. Susan Rice, who was one of the most influential names of the former Obama's presidency is heading the Political Domestic Council, a key position to establish bridges with Congress and interest groups.

During his career, Biden acted as the Chair of the Senate Foreign Relations Committee (200I/2003 e 2007/2009), in commissions that dealt with international issues such as drug trafficking, immigration and was Obama's special envoy in several talks (Brazil, Central America, the Middle East, technology). So, it was expected that he surrounded himself with people that were part of his inner circle. Added to this continuity, innovation is also part of this agenda, a dimension that can be best noted by analyzing

55 Professor of International Relations at UNIFESP and the Graduate Programs of International Relations San Tiago Dantas UNESP/UNICAMP/PUC-SP and of International Political Economy/UFRJ. NERINT/UFRGS and CNPq Researcher. E-mail: crispece@gmail.com 
documents such as the "Interim Strategic Guidance"56 (ISG). The goal of the ISG is to establish directives that will be better developed in the National Security Strategy. Two issues stand out: America is Back and Build Back Better, that sum up this continuity-innovation duality.

One of the most relevant features of ISG is to emphasize the correlation of domestic and foreign policies, which Biden defined as "the foreign policy of the middle class" in his inaugural speech ${ }^{57}$. This statement was an answer to the America First and Make America Great Again catch phrases of Trump's government that accused the democrats of being uninterested in the American people. Another significant point is the identification of immediate and long range priorities (in which human rights, identity agenda and the rethinking of US bilateral and multilateral pacts are included).

These immediate priorities are listed in the ISG: the fight against covid-Ig and the strengthening of global health security, domestic and foreign economic recovery promoting stability and social inclusion, the renewal of democracy and the fight against the dangers of authoritarian and nationalistic violence, the humanization and greater efficacy of the immigration system, the revitalization of interstate and multilateral partnerships, the fight against the climate crisis and the promotion of the green energy revolution, secure the technological leadership and deal with China's threat, defined as the greatest geopolitical test of the 2ist century. Other menaces are Russia, Iran, North Korea and Yemen.

In the geopolitical field, the ISG deals with the recurring issue of US grand strategy to: "Promote a favorable distribution of power to deter and prevent adversaries from directly threatening the United States and our allies, inhibiting access to the global commons, or dominating key regions." In order to do this, the US must "negotiate from a position of strength" and to promote the Armed Forces global posture review.

Regarding the practical arena, this is represented by the halting the process of troops relocation as promised by Trump, such as the withdrawal from Afghanistan and the rescaling of the North Atlantic Organization (NATO) staff in Germany. Another priority is to rebuild US-European Union (EU) strategic relations to counterbalance China and Russia. In the economic arena, either with the EU or the United Kingdom (UK), prospects are limited. For the UK, launching a more comprehensive bilateral trade agreement with the US is seen as essential to easy BREXIT's negative impacts, but on Biden's

56 THE WHITE HOUSE. 202I. Interim Strategic Guidance. Available at: https://www. whitehouse.gov/wp-content/uploads/202I/03/NSC-IV2.pdf.

57 THE WHITE HOUSE. 202I. Biden's Inaugural Address. January 20th, 202I. Available at:https://www.whitehouse.gov/briefing-room/speeches-remarks/202I/OI/20/inauguraladdress-by-president-joseph-r-biden-jr/. 
side there are, so far, no signs.

The US are once more engaged in the World Health Organization (WTO), promising to take part in the global efforts to fight covid-I9, support to vaccination in the framework of the global COVAX Facility alliance, the creation of a new international pact to deal with health emergencies and the donation of vaccine shots (confirmed only for Canada and Mexico). All in all, the US are in disadvantage considering the vaccine geopolitical agenda (understood as the production, distribution and easy access). In this arena, Russia, India and China are being more effective, mainly in South-South Cooperation (SSC).

When dealing with China, the main changes refer to the tactical movements and personal styles of Biden and Trump, as there is no adjustment in the level of menace: China is the main threat to the hegemonic position. One may not use terms such as "trade war", "the Chinese virus", but the expectation of a reset for the relations is very misleading, as March events show.

The first refers to the status change of the Quad- Quadrilateral Security Dialogue composed by the US, Japan, Australia and India. Created in 2004 as an advisory committee after the tsunami's humanitarian crisis, the Quad was almost inactive in the following years. Its restart is part of the update process of the Pacific Military Command (USPACOM), enlarged and reformulated as the Indo-Pacific Military Command (USINDOPACOM) by Obama, as a means to uphold the US and its allies free access to the Indian and Pacific Oceans and adjacent seas (as the South China Sea- SCS).

The Quad has gained a decisive role in the reactivation of the Asian Pivot in its warlike dimension, and further on, economical. It is a direct answer to the Chinese doctrine defined by the Pentagon as A2/AD (anti-access/area denial) that would prevent the free passage in the region and the signature of RCEP (Regional Comprehensive Economic Partnership) between fifteen Asian countries, including China and Japan (India opted out). The goals of this framework and other initiatives are to contain and to promote the dissuasion of China through multilateralism and the deepening of bilateral ties with key states, namely Japan, India and Australia.

The second corresponds to the bilateral summit in Alaska, that was instrumental, added to the repositioning of US fleet in the SCS and the European-US condemnations against China for human rights violations, to make US stands clear. For both powers, it was a kind of mutual acknowledgement of the new dynamics of the relation from now on. The US reinforced ISG goal "to negotiate in a position of strength" and China is gradually playing a more assertive role. When taking into account diplomatic incidents, the period focused on Russia, and the accusations of mistreatment 
of the opposition, interference in US democratic process and its elections and the accusation that Putin was a "killer".

The most sensitive issue is migration, since Biden's inauguration and the promise of reform led to a greater influx of migrants to the borders, mainly children. Mostly, the origins of these migrants are Guatemala, El Salvador and Honduras (the northern Central America triangle) and, in fewer numbers, Mexico. The challenge is to deal with unguarded children and migrants already in custody and to stop the entry in an open door fashion. Biden reinstated the asylum and refugee programs for immigrants that can prove political persecution and life threatening violence and drug trafficking, but the border crisis is active.

Brazil's name is not mentioned in this document and the bilateral relation is mostly protocol due to the alignment to previous Trump's government, the delay in recognizing Biden's victory and the disagreements on the environmental and human rights agenda. However, some civil society sectors in the US represented by the NGO "The US Network for Democracy in Brazil" published the report "Recommendations on Brazil to President Biden and the New Administration" 58 in which they demand harsh measures against the Brazilian government. These measures such as economic embargos, closed borders and aid cuts should have limited application and be avoided by the US, which is not seeking to remove Brazil from its sphere of influence.

However, one cannot underestimate the possibility of pressures, even soft ones, in order to answer, domestically, to demands by groups that are key for the Democratic Party electoral ambitions. Still in March, an example was Brazil's inclusion in the 2020 Country Reports on Human Rights Practices 59 issued by the Department of State, pinpointing the seriousness of Brazil's current government attacks to the press and the disrespect for basic and fundamental human rights. The recent change in the command of Brazil's Ministry of Foreign Relations with Ambassador Ernesto Araujo departure and the indication of Carlos Alberto Franco França will only have concrete results with adjustments in the government's rhetoric and agenda following Biden's priorities.

A greater presence of the State in technological investments and USAID programs, the repositioning of troops in key regions are expected

58 The US Network for Democracy in Brazil. 202I. Recommendations on Brazil to President Biden and the New Administration. Available at: https://www.cartacapital.com.br/wp-content/ uploads/2021/02/documento-US-Network-for-Brazils-Democracy.pdf .

59 THE STATE DEPARTMENT. 2020. Country Reports on Human Rights Practices. Available at: https://www.state.gov/reports/2020-country-reports-on-human-rights-practices/. And THE STATE DEPARTMENT. 2020. Brazil 2020 Human Rights Report. Available at: https://www. state.gov/wp-content/uploads/202I/03/BRAZIL-2020-HUMAN-RIGHTS-REPORT.pdf. 
as next steps, as soon as the covid-I9 economic crisis is managed. Biden will have to deal with domestic divisions and pressures for more regime change interventionism in the peripheries of the system, in the midst of the geopolitical and geoeconomical priorities of China's containment. The changes of the Biden era are more tactical than strategic: America is back, even though it never really went anywhere.

\section{Latin America and the Beginning of an Electoral Cycle: A New Turn to the Left?}

Leonardo Granato ${ }^{60}$

In the midst of a multifaceted crisis, which today has at its core the covid-I9 pandemic, Latin America is starting, in 202I, a new electoral cycle. By 2025 there will be presidential elections in nineteen countries in the region, and their results will indicate new correlations of forces around specific agendas to face the challenges that the referred crisis imposes in each national context. In 202I, elections are held in Ecuador, Peru, Nicaragua, Chile and Honduras. In 2022 it will be the turn of Costa Rica, Colombia and Brazil, and in 2023, Guatemala, Argentina and Paraguay. In 2024, there are also the cases of Mexico, El Salvador, Panama, Dominican Republic, Uruguay and Venezuela. Finally, in 2025 it will be Cuba and Bolivia turn. In this text, we seek to present an interpretative synthesis of the main facts that have been part of the beginning of this new electoral cycle, linking them to the electoral trends that, since the beginning of the 2Ist century, have been registered in the region.

As in the electoral scenario at the beginning of the last decade, mainly in South America, this new cycle also seems to signal, although, for the time being, not conclusively, a resumption of the predominance of leftwing political forces. This possibility, in addition to being explained by the restrictive agendas of conservative neoliberal governments in the face of the current crisis in the region, needs to be contextualized based on the "electoral waves" in the continent and the recovery of some historical facts, in a broader perspective.

From the early 2000 s, in the context of a crisis of neoliberal hegemony and in a favorable external environment, linked not only to the resumption of world growth, but also to the Chinese rise to the condition of economic and political power at the global level, a new wave of popular and progressive

6o Professor of Public Administration at UFRGS. Researcher at NERINT. 
governments has spread throughout the region. Reference is made mainly to Chávez's electoral victories in Venezuela; Morales, in Bolivia; Correa, in Ecuador; Lula da Silva and Rousseff, in Brazil; the Kirchners, in Argentina, in addition to those that took place in other countries such as Chile, El Salvador, Honduras, Nicaragua, Paraguay and Uruguay. Countries such as Mexico, Colombia and Peru, in fact, maintained conservative governments.

Despite the diversity of historical experiences in the various countries, it can be said that the new governments sought, under the implementation of various national and social agendas for inclusive development, to achieve some margin for the reform of the neoliberal order. However, after the 2008 global economic and financial crisis and the end of the "commodities cycle", this change in the correlation of forces, expressed in the "left turn" of the first decade of 2000 , gave way under the pressure of the dominant classes, which they judged the political-economic model of support for these progressive governments to be exhausted.

Such pressure culminated in a political scenario marked by facts such as the dismissal of the representatives of Honduras (2009), Paraguay (2012), Brazil (2016) and Bolivia (2019), the acute crisis in Venezuela, and Macri's electoral victories in Argentina (20I5), Moreno, Ecuador (20I7), Piñera, Chile (2018), Bolsonaro, Brazil (2019) and Lacalle Pou (2020), Uruguay. Thus, through a "turn to the right", the conservative neoliberal ideology has regained momentum, especially with regard to the need for new adjustment measures and liberalizing structural reforms, the result of which has resulted in greater economic and financial opening, greater concentration income, increased poverty, unemployment, precarious work and basic public services, among other factors that, on the whole, would worsen due to the outbreak of the covid-I9 pandemic.

On the other hand, the victories, in the left field, of López Obrador, in Mexico (20I8), of Alvarado, in Costa Rica (20I8), of Fernández, in Argentina (2019), of Cortizo, in Panama (2019) and, recently, from Arce, Bolivia (2020), as well as the Maduro government's resilience in Venezuela in the face of political offensives and economic sanctions imposed by the United States and its national allies to change government, fundamentally demonstrate the difficulty that conservative neoliberal projects present in making themselves electorally viable in front of the popular masses, and that prevents the cycle of popular and progressive governments in the continent from being ended.

Likewise, the uprisings and popular demonstrations that hit Ecuador, Chile and Colombia, between the months of October and December 20I9, and which had as a corollary, in the Chilean case, the victory of the "Apruebo" option for the convening of a Convention Constitutional Framework for the drafting of a new Constitution, also contribute to establishing such an 
understanding. Finally, in addition to the presidential elections, municipal elections also serve as a political barometer in several countries. For example, in the Brazilian case, in the municipal elections of November 2020 , there was a recovery of the traditional center-right - whose votes, in the 2018 elections, were absorbed by Bolsonarism -, as well as new leaders of the left, such as Boulos and D'Ávila, from alternative parties to the Workers' Party - of former President Lula - emerged.

In this context, the expressive defeat of Bolsonaro's candidates in the municipal elections, as well as the recent annulment of Lula's condemnations by the Supreme Federal Court - which makes the former president eligible for the 2022 election -, seem to signal difficulties for a Bolsonaro's eventual re-election, which is expected to bear the political consequences of an unprecedented health crisis.

The year 202I will also be marked, as stated at the beginning of this text, by the presidential electoral disputes in Ecuador, Peru, Nicaragua, Chile and Honduras. In the Chilean case, there is also the peculiarity of regional and municipal elections, in addition to that relating to the members of the Constituent Convention, which will have nine months to draft the new constitutional text. In national contexts characterized by severe economic, social and health crises, the dynamics of polarization and fragmentation seem to weaken the electoral strife in these countries. Returning to the case of Chile, for example, the popular uprisings and the constitutional reform process seem to have anticipated the possible end of the period of alternation of the Bachelet-Piñera governments, which have been in force since 2006 . The fact is that in the face of the elections scheduled for the month of November this year, it is fragmentation and internal tensions that today characterize the traditional center-right bloc, represented by the Chile Vamos alliance, and the left, bloc represented by Unidad Constituyente, making it difficult to reach consensus among the main political forces from the country.

In the case of Ecuador, the great dispute is structured between the "correist" left (Unión por la Esperanza) and the "anti-correist" center-right (Creating Opportunities). With regard to postal services, moving away from the current president Moreno - who came to the presidency as heir to expresident Correa, but ended up breaking with him -, this block sought, at first, to emulate the Argentine experience and think of a formula to have Correa as vice president, just as Fernández de Kirchner did on the ticket with Alberto Fernández.

However, due to his conviction for corruption, his example was Morales, who was also unable to run, and who supported his party's candidate (Movimiento al Socialismo), the current president Arce, who was a winner. In the February 2016 electoral dispute, racist candidate Arauz won more than 
$30 \%$ of the vote, facing the candidate of a fragmented center-right - with more than fifteen candidates for the presidency -, banker Lasso, who won around the $19 \%$ of the preference - having obtained the support of a historical force in the country, the Social Cristiano Party -. The second round of the presidential elections in Ecuador will be held on April II, the date on which the presidential elections will also be held in Peru. But the coincidences between both countries do not stop there. Peru, which has been facing turbulent times with conservative governments since 20I6, and which had two presidents overthrown in late 2020 , also faces a polarization between the extreme right, with the candidacy of Aliaga (Renovación Popular) and the field of progressivism, which has Mendonza (Juntos por el Perú) among its most outstanding candidates, as well as a high fragmentation among political forces, reflected in the more than twenty competing presidential slates.

Finally, in Central America, there are also the cases of Honduras and Nicaragua, which will also face presidential elections this year. Honduras, a country that has been polarized since Zelaya was overthrown in 2009, had primary and internal elections in March, marked by fragmentation and competition from conservative National and Liberal parties, which chose Asfura (with more than $72 \%$ of the votes) and Rosenthal (with more). 54\% of the votes), as the favorites to contest for the said parties, respectively, the presidential elections of the month of November. The left field is represented by the alliance Libertad $y$ Refundación (Libre), which had the wife of former President Zelaya, Xiomara Castro, as the main candidate, with almost $80 \%$ of the valid votes. Certainly, in the current context of a strong crisis in the country, the National governing party will have to work hard to impose itself on a progressivism that has been strengthening. In the case of Nicaragua, there is still uncertainty as to whether current President Ortega of the Sandinist Front will run for election in November.

Ortega was the president of Nicaragua between I985 and I990 and returned to office in 2006, having been reelected in 2011 and 2016 . The opposition, brought together in the Coalición Nacional, created in January 2020, and integrated by the Unidad Nacional Azul y Blanco, the Movimiento Campesino and four other political parties, have already had their first casualty. Still in 2020, Alianza Cívica por la Justicia y la Democracia ended up leaving the opposition front, highlighting the difficulties of achieving its unity in the face of the presidential dispute, the result of which will be key to the implementation of measures that will make the country overcome the violence and poverty that permeates it.

In short, Latin America is entering the third decade of the 2Ist century and into a new electoral cycle under the effects of an unprecedented multidimensional crisis, whose specific characteristics can only be defined in 
relation to each particular national context. Just as the current phenomena of polarization and fragmentation, which are in fact seen in the political scene of most countries in the region can be better explained by adopting a broader historical perspective of the political processes that have been taking place in the region, the possibilities of a resumption of the forces of the left, in this new decade, they appear as a possible horizon in face of, to a great extent, the limitations that the conservative responses to the crisis, and to the popular demands in general, have been revealing. 